\title{
Flagellimonas eckloniae gen. nov., sp. nov., a mesophilic marine bacterium of the family Flavobacteriaceae, isolated from the rhizosphere of Ecklonia kurome
}

Correspondence Jung-Hyun Lee jlee@kordi.re.kr

\author{
Seung Seob Bae, Kae Kyoung Kwon, Sung Hyun Yang, Hee-Soon Lee, \\ Sang-Jin Kim and Jung-Hyun Lee
}

Marine Biotechnology Center, Korea Ocean Research and Development Institute, Ansan PO Box 29, 425-600, Republic of Korea

\begin{abstract}
A marine bacterium, DOKDO $007^{\top}$, was isolated from the rhizosphere of the marine alga Ecklonia kurome collected from Dokdo Island, Korea, in October 2004. The strain produced orange-coloured colonies on marine agar 2216. 16S rRNA gene sequence analysis indicated that the novel isolate belonged to the family Flavobacteriaceae and showed relatively high sequence similarities with members of the genus Muricauda (92.0-94.0\%). Phylogenetic analysis based on nearly complete $16 \mathrm{~S}$ rRNA gene sequences revealed that the novel isolate shared a lineage with members of the genera Muricauda and Costertonia. Cells were aerobic, Gram-negative rods producing non-diffusible carotenoid pigments. In contrast to all other members of the family Flavobacteriaceae, cells of DOKDO $007^{\top}$ were motile by means of a polar flagellum. Optimal growth occurred in the presence of $3.5-4 \%(\mathrm{w} / \mathrm{v})$ sea salts (corresponding to $2.7-3.1 \% \mathrm{NaCl}$ ), at $\mathrm{pH} 8$ and at temperatures of $26-29^{\circ} \mathrm{C}$. The novel strain required $\mathrm{Ca}^{2+}$ ions in addition to $\mathrm{NaCl}$

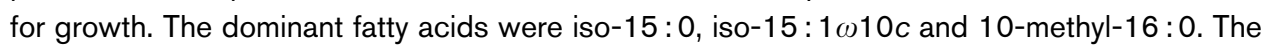
major respiratory quinone was MK-6. The DNA G+C content was 56.3 mol\%, an unusually high value for members of the family Flavobacteriaceae. On the basis of these polyphasic taxonomic data, strain DOKDO $007^{\top}$ should be classified as representing a new genus and novel species in the family Flavobacteriaceae, for which the name Flagellimonas eckloniae gen. nov., sp. nov. is proposed. The type strain is DOKDO $007^{\top}\left(=\mathrm{KCCM}^{\top} 2307^{\top}=\mathrm{JCM} 13831^{\top}\right)$.
\end{abstract}

The family Flavobacteriaceae belongs to the phylum Bacteroidetes (previously known as Cytophaga-FlavobacteriumBacteroides), which groups chemoorganotrophic, nonspore-forming, Gram-negative rods that are non-motile or motile by gliding. Members of the family can be nonpigmented or pigmented by carotenoid and/or flexirubin pigments depending on the genus. Menaquinone 6 serves as their only or major respiratory quinone (Bernardet et al., 1996, 2002). Some members of the family, such as Arenibacter latericius, Mesonia algae, Maribacter ulvicola and Zobellia galactanovorans (Barbeyron et al., 2001; Ivanova et al., 2001; Nedashkovskaya et al., 2003a, 2004b) have been isolated from a diverse range of marine macroalgae. Here, we propose that strain DOKDO $007^{\mathrm{T}}$, originating from the rhizosphere of a marine macroalga, represents a new genus in the family Flavobacteriaceae.

The GenBank/EMBL/DDBJ accession number for the 16S rRNA gene sequence of strain DOKDO $007^{\top}$ is DQ191180.

Transmission and scanning electron micrographs of cells of strain DOKDO $007^{\top}$ are available as supplementary material in IJSEM Online.
The marine macroalga Ecklonia kurome was collected along the seashore of Dokdo Island, Korea, in October 2004. A small piece of algal rhizosphere was crushed in $2 \mathrm{ml}$ sterile seawater which was then spread onto marine agar 2216 (MA; Difco) and cultivated at $30^{\circ} \mathrm{C}$ for 7 days. Among the morphologically distinct colonies that grew on MA, a tiny orange-coloured colony was isolated, designated DOKDO $007^{\mathrm{T}}$, and preserved in marine broth $2216(\mathrm{MB}$; Difco) containing $20 \%$ glycerol at $-80^{\circ} \mathrm{C}$. The isolate was further cultivated on MA or in MB for morphological and biochemical characterization.

Unless otherwise stated, the minimal standards for describing novel taxa in the family Flavobacteriaceae proposed by Bernardet et al. (2002) were tested according to previously described methods (Bae et al., 2005; Sohn et al., 2004). Transmission and scanning electron micrographs were taken using JSM-6700F (JEOL) and JEM-2000EXII (JEOL) electron microscopes, respectively. Gliding motility was investigated according to the method described by Bowman (2000) on bacteria grown for $24 \mathrm{~h}$ at $20^{\circ} \mathrm{C}$. Flagellar motility was examined using a $24 \mathrm{~h} \mathrm{MB}$ culture under a light 
microscope (Axioplan; Zeiss). Cellular pigments were extracted with $3 \mathrm{ml}$ methanol/acetone mixture $(1: 1, \mathrm{v} / \mathrm{v})$ from culture grown on MA and their absorption spectra were measured with a spectrophotometer (UV-2410PC; Shimadzu). Flexirubin-type pigments were detected by placing a drop of $20 \% \mathrm{KOH}$ on colonies (Fautz \& Reichenbach, 1980). The degradation of starch and casein was tested according to Smibert \& Krieg (1994). Bacterial suspensions used to inoculate API 20NE (bioMérieux) and Microlog GN2 (Biolog) systems were prepared in $3 \%$ sea salts (Sigma) solution. The commercial sea salts preparation was also used to test the salt tolerance range of the novel strain. The physiological, biochemical and morphological characteristics of strain DOKDO $007^{\mathrm{T}}$ are given below, in the genus and species descriptions and in Table 1.

Gliding motility was not observed. Flagellar motility was observed and confirmed by the presence of a single polar flagellum on some bacterial cells as shown by transmission electron microscopy (see Supplementary Fig. S1 in IJSEM Online). This is a very unusual characteristic in the family Flavobacteriaceae. Cells of Polaribacter irgensii have been shown to display a polar flagellum, although motility has never been observed (Gosink et al., 1998). In contrast, the motility observed in cells of Costertonia aggregata is not of the gliding type, but the presence of flagella has not been reported (Kwon et al., 2006).

The presence of $\mathrm{NaCl}$ alone in the medium did not support the growth of strain DOKDO $007^{\mathrm{T}}$. We therefore tested the requirement for three other seawater components; $\mathrm{CaCl}_{2} \cdot 2 \mathrm{H}_{2} \mathrm{O}, \mathrm{KCl}$ and $\mathrm{MgCl}_{2} \cdot 6 \mathrm{H}_{2} \mathrm{O}$. All combinations of these components at concentrations of $0.18 \% \mathrm{CaCl}_{2} \cdot 2 \mathrm{H}_{2} \mathrm{O}$, $0.055 \% \mathrm{KCl}$ and $0.59 \% \mathrm{MgCl}_{2} \cdot 6 \mathrm{H}_{2} \mathrm{O}$ were added to modified ZoBell $2216 \mathrm{e}$ medium containing $5 \mathrm{~g}$ yeast extract, $1 \mathrm{~g}$ peptone, $30 \mathrm{~g} \mathrm{NaCl}$ and $0.01 \mathrm{~g} \mathrm{FePO}_{4}$ per litre of distilled water. Growth was observed only in the presence of $\mathrm{Ca}^{2+}$ ions, in addition to $\mathrm{NaCl}$. Growth also occurred in the presence of $2.5-7 \%$ of the commercial sea salts preparation.

The cellular fatty acid methyl ester profile was determined according to Sohn et al. (2004) on bacteria grown in MB for 3 days at $25^{\circ} \mathrm{C}$. The dominant fatty acids of strain DOKDO $007^{\mathrm{T}}$ were iso- $15: 0(41.8 \%)$, iso- $15: 1 \omega 10 c(11.4 \%), 10$ methyl-16:0 $(9.2 \%), 15: 0(7.0 \%)$, unidentified fatty acid ECL $18.056(6.5 \%)$ and $16: 1 \omega 7 c(6.0 \%)$. The strain also contained small amounts of anteiso-15:0 $(2.5 \%)$, iso- $16: 0$ $(1.5 \%), 16: 0(1.4 \%)$, iso-14:0 (1.3\%) and iso-13:0 $(1.3 \%)$. The novel strain contained a relatively large amount of iso-15:0, a characteristic shared with C. aggregata (Kwon et al., 2006) (Table 1).

Using the HPLC analysis method of Collins (1985), the major respiratory quinone was determined to be MK-6. The DNA G + C content was 56.3 mol\% as determined by HPLC using a symmetry reversed-phase C18 column (Waters; Stackebrandt \& Liesack, 1993). Robiginitalea biformata is the only other member of the family Flavobacteriaceae that shows such a high DNA G $+\mathrm{C}$ content (Cho \& Giovannoni, 2004).

Extraction of the genomic DNA and amplification of the $16 \mathrm{~S}$ rRNA gene were conducted according to Sohn et al. (2004). A phylogenetic tree featuring strain DOKDO $007^{\mathrm{T}}$ and closely related genera was generated based on Jukes and Cantor or maximum-likelihood distance models with neighbour-joining or maximum-parsimony algorithms. A total of 1309 unambiguously aligned sequences were compared. The closest neighbour was Muricauda aquimarina ( $94.0 \%$ gene sequence similarity), followed by Muricauda ruestringensis (93.5\%), Muricauda flavescens $(92.0 \%)$ and C. aggregata KOPRI $13342^{\mathrm{T}}(91.3 \%)$. Phylogenetic analysis based on 16S rRNA gene sequences of previously published strains revealed that strain DOKDO $007^{\mathrm{T}}$ shared a phyletic line with the genera Muricauda and Costertonia, though occupying a distinct position (Fig. 1).

Strain DOKDO $007^{\mathrm{T}}$ shared many characteristics with closely related members of the family Flavobacteriaceae, including the type of major respiratory quinone, the range of temperature and $\mathrm{pH}$ supporting growth and the requirement for salt and oxygen. Some features, such as (i) the requirement of a seawater component $\left(\mathrm{Ca}^{2+}\right)$ in addition to $\mathrm{NaCl}$ for growth, the high amount of iso-15:0 and flagellar motility and (ii) the high DNA G + C content are only shared with C. aggregata and Robinginitalea biformata, respectively. However, the presence of $16: 1 \omega 7 c(6.0 \%)$ and 10-methyl-16:0 (9.2\%) and the absence of oxidase activity are major differences with closely related members of the family Flavobacteriaceae (Table 1). This new strain should therefore be recognized as representing a novel member of the family Flavobacteriaceae. We suggest a new genus, Flagellimonas, and propose the strain as Flagellimonas eckloniae gen. nov., sp. nov.

\section{Description of Flagellimonas gen. nov.}

Flagellimonas (Fla'gell.i.mon.as. L. n. flagellum a whip and in bacteriology, a flagellum; L. fem. n. monas a unit, monad; N.L. fem. n. Flagellimonas a bacterium motile by means of a flagellum which is unusual for a member of the family Flavobacteriaceae).

Cells are strictly aerobic, motile, Gram-negative rods. Produce non-diffusible carotenoid pigments, but flexirubin-type pigments are absent. The major respiratory quinone is MK-6. The major cellular fatty acids are iso- $15: 0$,

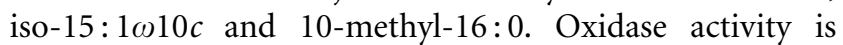
absent, but catalase activity is present. The DNA G $+\mathrm{C}$ content of the type species is $56.3 \mathrm{~mol} \%$. As determined by $16 \mathrm{~S}$ rRNA gene sequence analysis, the genus Flagellimonas is a member of the family Flavobacteriaceae, phylum Bacteroidetes. The type species is Flagellimonas eckloniae.

\section{Description of Flagellimonas eckloniae sp. nov.}

Flagellimonas eckloniae (ec.klo.ni' a.e. N.L. fem. n. Ecklonia scientific genus name of the marine alga from which the bacterium was isolated; N.L. gen. n. eckloniae of Ecklonia). 
Table 1. Phenotypic characteristics that differentiate strain DOKDO $007^{\top}$ from closely related members of the family Flavobacteriaceae

Taxa: 1, DOKDO $007^{\mathrm{T}}$; 2, Muricauda; 3, Costertonia aggregata KOPRI $13342^{\mathrm{T}}$ (only species in genus); 4, Maribacter; 5, Zobellia; 6, Arenibacter; 7, Robiginitalea biformata HTCC $2501^{\mathrm{T}}$ (only species in genus). Data are from Barbeyron et al. (2001), Bruns et al. (2001), Cho \& Giovannoni (2004), Ivanova et al. (2001), Kwon et al. (2006), Nedashkovskaya et al. (2003b, 2004a, b, c) and Yoon et al. (2005a, b). Fatty acid percentages amounting to $<3 \%$ of the total fatty acids in all strains are not included. For fatty acid analysis, some bacterial strains were not cultivated in the same conditions and different analysis procedures were used. All strains are positive for catalase activity, require oxygen for growth, have MK-6 as a major respiratory quinone and do not require specific growth factors or produce indole. + , Positive; -, negative; ND, not determined; V, variable.

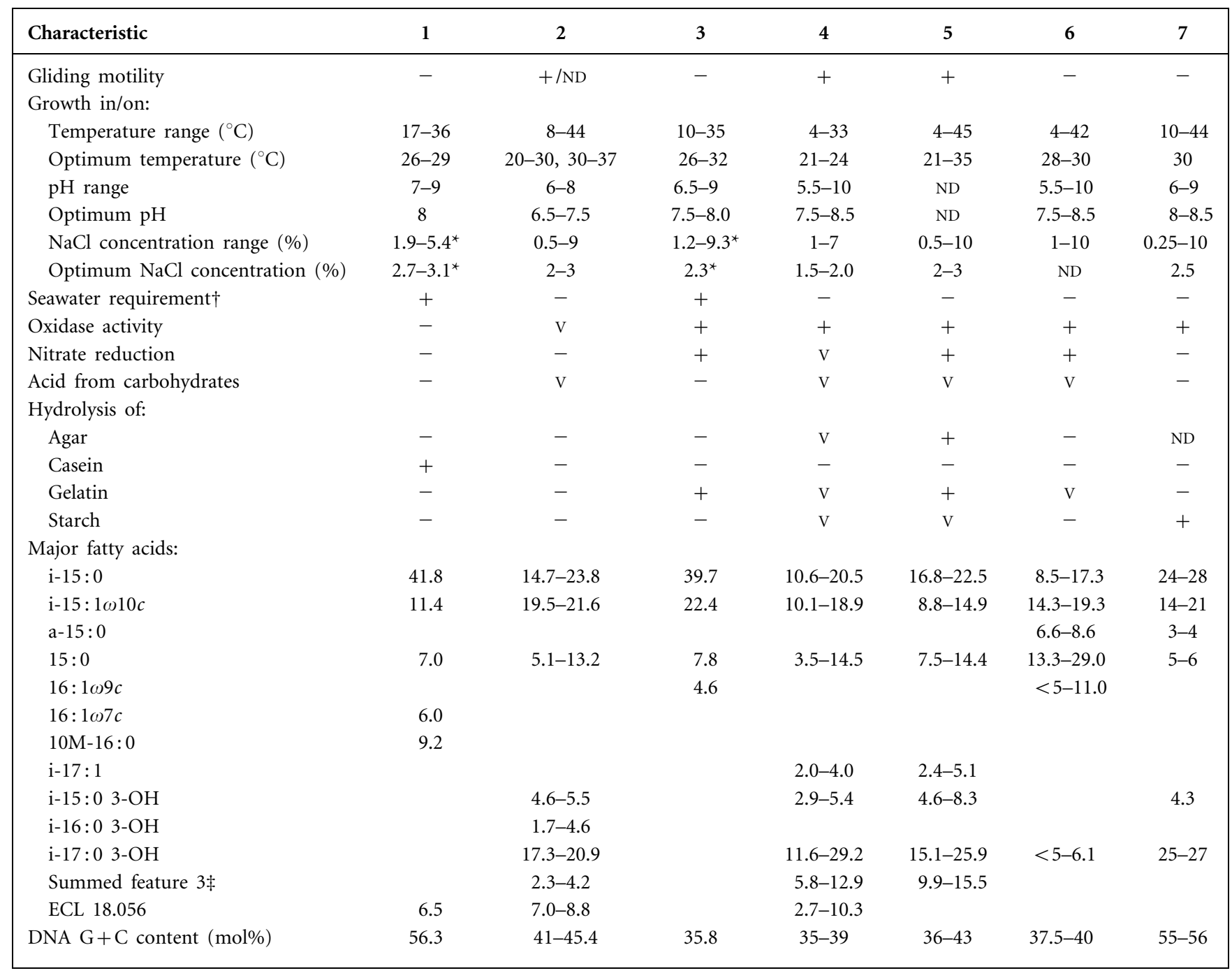

${ }^{*}$ Sea salt concentration was converted to $\mathrm{NaCl}$ concentration.

$\dagger$ Requirement of seawater indicates that $\mathrm{Na}^{+}$alone does not support growth. The strain requires additional cations present in seawater for growth, such as $\mathrm{Mg}^{2+}, \mathrm{Ca}^{2+}$ and/or $\mathrm{K}^{+}$.

$\ddagger$ Summed feature 3 contains $16: 1 \omega 7 c$ and/or iso-15:0 2-OH.

Displays the following properties in addition to those given in the genus description. Cells are $1.1-2.3 \mu \mathrm{m}$ in length and $0.2-0.36 \mu \mathrm{m}$ in diameter and motile by means of a single polar flagellum (see Supplementary Fig. S1 in IJSEM Online). Gliding motility is not observed. Cells form irregular aggregates during growth in MB. After 3 days of incubation on MA at $25^{\circ} \mathrm{C}$, colonies are orange-pigmented, opaque, convex and uniformly circular. Absorption maxima of the pigments extracted with solvent solution are observed at 450 and $473 \mathrm{~nm}$. Growth occurs between 17 and $36^{\circ} \mathrm{C}$, at $\mathrm{pH} 7-9$ and in the presence of $2.5-7 \%$ sea salts. Requires $\mathrm{Na}^{+}$and $\mathrm{Ca}^{2+}$ ions for growth. Optimal growth requires the presence of $3.5-4 \%(\mathrm{w} / \mathrm{v})$ sea salts (corresponding to $2.7-3.1 \% \mathrm{NaCl}$ ), $\mathrm{pH} 8$ and $26-29^{\circ} \mathrm{C}$. Cells hydrolyse casein, 


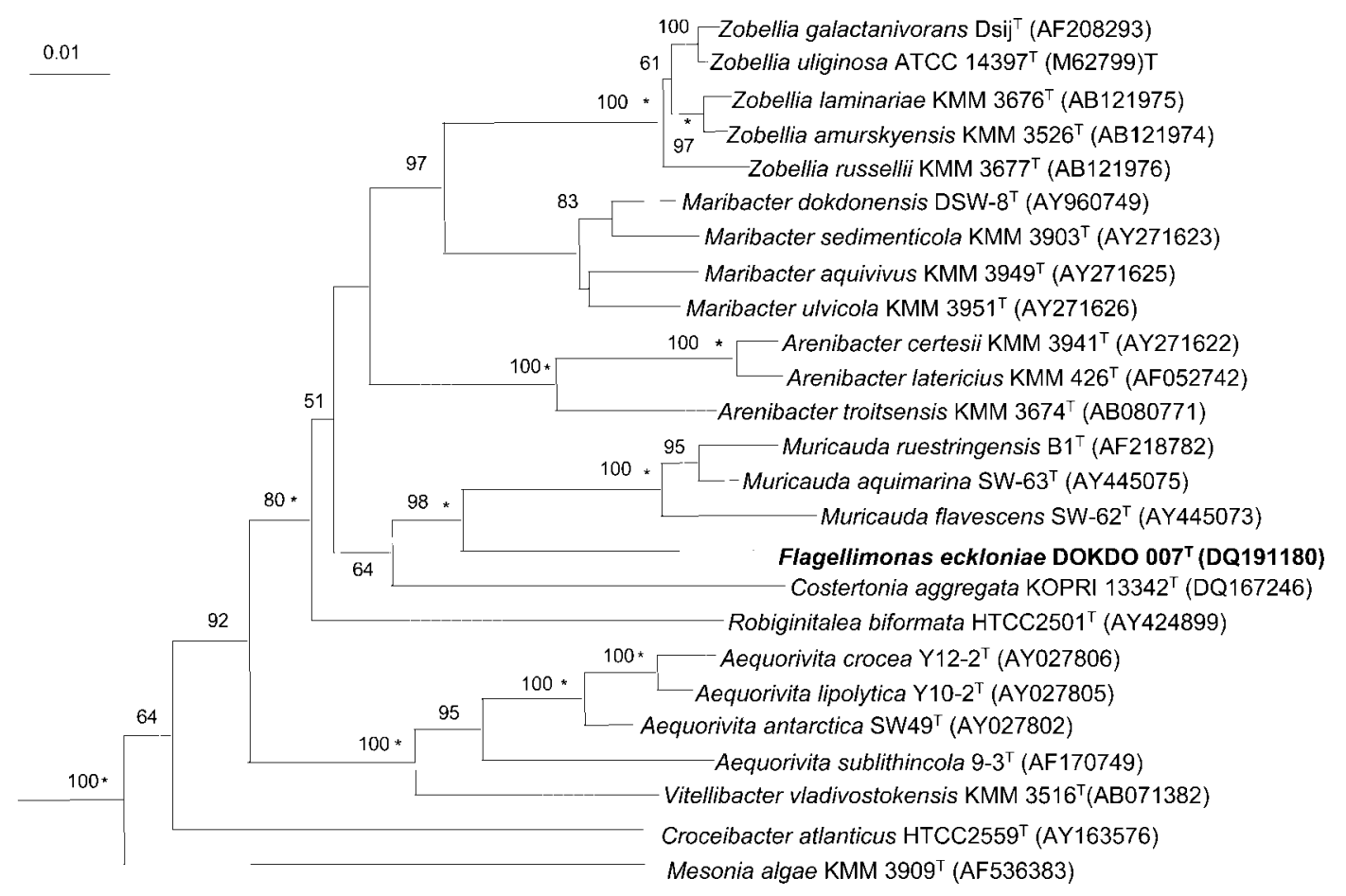

Fig. 1. Phylogenetic tree based on nearly complete $16 \mathrm{~S}$ rRNA gene sequences (1309 unambiguously aligned base pairs) showing the relationship between strain DOKDO $007^{\top}$ and related members of the family Flavobacteriaceae. The $16 \mathrm{~S}$ rRNA gene sequences of Bacteroides fragilis ATCC $25285^{\top}$ (GenBank accession no. M61006) and Sphingobacterium spiritivorum DSM 2582 ${ }^{\top}$ (AJ459411) served as outgroups (not shown). The tree is based on the Jukes and Cantor distance model and the neighbour-joining algorithm. Bootstrap values $>50 \%$ for 1000 resamples are shown. Asterisks indicate the bootstrap values $>70 \%$ for 1000 resamples that were also found in the tree generated by the maximum-likelihood distance model and maximum-parsimony algorithm. Bar, 0.01 nucleotide substitutions per nucleotide position.

but not agar, gelatin or starch. In API 20NE test strips, $\beta$-glucosidase, $\beta$-galactosidase and protease (gelatin hydrolysis) activities are positive, but reduction of nitrate to nitrogen, glucose acidification, production of $\mathrm{H}_{2} \mathrm{~S}$ and arginine dihydrolase and urease activity are negative; acetoin production is weakly positive. In Biolog GN2 MicroPlates, cells utilize dextrin, cellobiose, L-fucose, D-galactose, gentiobiose, $\alpha$-D-glucose, maltose, D-mannose, sucrose, D-trehalose, turanose, D-glucuronic acid, DL-lactic acid and L-aspartic acid. Weakly positive results are recorded for the utilization of glycogen, $\mathrm{D}$-fructose, $\mathrm{D}$-melibiose, methyl $\beta$-D-glucoside, D-raffinose, L-rhamnose, $\alpha$-ketobutyric acid, $\alpha$-ketoglutaric acid, succinic acid, alaninamide, L-alanine, L-alanyl glycine, L-asparagine, L-glutamic acid, glycyl L-glutamic acid, hydroxyl-L-proline, L-leucine, L-proline, L-threonine, urocanic acid, phenylethylamine and glucose 1-phosphate. The dominant fatty acids are iso-15:0 (41.8\%), iso- $15: 1 \omega 10 c$ (11.4\%), 10-methyl-16:0 (9.2\%), $15: 0$ (7.0\%), unidentified fatty acid ECL $18.056(6.5 \%$,) and $16: 1 \omega 7 c(6.0 \%)$. Other characteristics are shown in Table 1.

The type strain, DOKDO $007^{\mathrm{T}}\left(=\mathrm{KCCM} 42307^{\mathrm{T}}=\mathrm{JCM}\right.$ $13831^{\mathrm{T}}$ ), was isolated from the rhizosphere of the marine alga Ecklonia kurome collected on Dokdo Island, Korea.

\section{Acknowledgements}

This work was supported by the 'Marine and Extreme Genome Research Center' program of the Ministry of Maritime Affairs and Fisheries, Korea and the 'Dokdo' Program (PM40201).

\section{References}

Bae, S. S., Lee, J.-H. \& Kim, S.-J. (2005). Bacillus alveayuensis sp. nov., a thermophilic bacterium isolated from deep-sea sediments of the Ayu Trough. Int J Syst Evol Microbiol 55, 1211-1215.

Barbeyron, T., L'Haridon, S., Corre, E., Kloareg, B. \& Potin, P. (2001). Zobellia galactanovorans gen. nov., sp. nov., a marine species of Flavobacteriaceae isolated from a red alga, and classification of [Cytophaga] uliginosa (ZoBell and Upham 1944) Reichenbach 1989 as Zobellia uliginosa gen. nov., comb. nov. Int J Syst Evol Microbiol 51, 985-997.

Bernardet, J.-F., Segers, P., Vancanneyt, M., Berthe, F., Kersters, K. \& Vandamme, P. (1996). Cutting a Gordian knot: emended classification and description of the genus Flavobacterium, emended description of the family Flavobacteriaceae, and proposal of Flavobacterium hydatis nom. nov. (Basonym, Cytophaga aquatilis Strohl and Tait 1978). Int J Syst Bacteriol 46, 128-148.

Bernardet, J.-F., Nakagawa, Y. \& Holmes, B. (2002). Proposed minimal standards for describing new taxa of the family 
Flavobacteriaceae and emended description of the family. Int J Syst Evol Microbiol 52, 1049-1070.

Bowman, J. P. (2000). Description of Cellulophaga algicola sp. nov., isolated from the surfaces of Antarctic algae, and reclassification of Cytophaga uliginosa (ZoBell and Upham 1944) Reichenbach 1989 as Cellulophaga uliginosa comb. nov. Int J Syst Evol Microbiol 50, 1861-1868.

Bruns, A., Rohde, M. \& Berthe-Corti, L. (2001). Muricauda ruestringensis gen. nov., sp. nov., a facultatively anaerobic, appendaged bacterium from German North Sea intertidal sediment. Int J Syst Evol Microbiol 51, 1997-2006.

Cho, J. C. \& Giovannoni, S. J. (2004). Robiginitalea biformata gen. nov., sp. nov., a novel marine bacterium in the family Flavobacteriaceae with a higher $\mathrm{G}+\mathrm{C}$ content. Int J Syst Evol Microbiol 54, 1101-1106.

Collins, M. D. (1985). Isoprenoid quinone analysis in classification and identification. In Chemical Methods in Bacterial Systematics, pp. 267-287. Edited by M. Goodfellow \& D. E. Minikin. London: Academic Press.

Fautz, E. \& Reichenbach, H. (1980). A simple test for flexirubin-type pigments. FEMS Microbiol Lett 8, 87-91.

Gosink, J. J., Woese, C. R. \& Staley, J. T. (1998). Polaribacter gen. nov., with three new species, $P$. irgensii sp. nov., $P$. franzmannii sp. nov. and $P$. filamentus sp. nov., gas vacuolate polar marine bacteria of the Cytophaga-Flavobacterium-Bacteroides group and reclassification of 'Flectobacillus glomeratus' as Polaribacter glomeratus comb. nov. Int J Syst Bacteriol 48, 223-235.

Ivanova, E. P., Nedashkovskaya, O. I., Chun, J., Lysenko, A. M., Frolova, G. M., Svetashev, V. I., Vysotskii, M. V., Mikhailov, V. V., Huq, A. \& Colwell, R. R. (2001). Arenibacter gen. nov., new genus of the family Flavobacteriaceae and description of a new species, Arenibacter latericius sp. nov. Int J Syst Evol Microbiol 51, 1987-1995.

Kwon, K. K., Lee, Y. K. \& Lee, H. K. (2006). Costertonia aggregata gen. nov., sp. nov., a mesophilic marine bacterium of the family Flavobacteriaceae, isolated from a mature biofilm. Int J Syst Evol Microbiol 56, 1349-1353.

Nedashkovskaya, O. I., Kim, S. B., Han, S. K., Lysenko, A. M., Rohde, M., Zhukova, N. V., Falsen, E., Frolova, G. M., Mikhailov, V. V. \& Bae, K. S. (2003a). Mesonia algae gen. nov., sp. nov., a novel marine bacterium of the family Flavobacteriaceae isolated from the green alga Acrosiphonia sonderi (Kutz) Kornm. Int J Syst Evol Microbiol 53, 1967-1971.

Nedashkovskaya, O. I., Suzuki, M., Vysotskii, M. V. \& Mikhailov, V. V. (2003b). Arenibacter troitsensis sp. nov., isolated from marine bottom sediment. Int J Syst Evol Microbiol 53, 1287-1290.

Nedashkovskaya, O. I., Kim, S. B., Han, S. K., Lysenko, A. M., Mikhailov, V. V. \& Bae, K. S. (2004a). Arenibacter certesii sp. nov., a novel marine bacterium isolated from the green alga Ulva fenestrata. Int J Syst Evol Microbiol 54, 1173-1176.

Nedashkovskaya, O. I., Kim, S. B., Han, S. K., Lysenko, A. M., Rohde, M., Rhee, M.-S., Frolova, G. M., Falsen, E., Mikhailov, V. V. \& Bae, K. S. (2004b). Maribacter gen. nov., a new member of the family Flavobacteriaceae, isolated from marine habitats, containing the species Maribacter sedimenticola sp. nov., Maribacter aquivivus sp. nov., Maribacter orientalis sp. nov. and Maribacter ulvicola sp. nov. Int J Syst Evol Microbiol 54, 1017-1023.

Nedashkovskaya, O. I., Suzuki, M., Vancanneyt, M., Cleenwerck, I., Lysenko, A. M., Mikhailov, V. V. \& Swings, J. (2004c). Zobellia amurskyensis sp. nov., Zobellia laminariae sp. nov. and Zobellia russellii sp. nov., novel marine bacteria of the family Flavobacteriaceae. Int J Syst Evol Microbiol 54, 1643-1648.

Smibert, R. M. \& Krieg, N. R. (1994). Phenotypic characterization. In Methods for General and Molecular Bacteriology. pp. 607-654. Edited by P. Gerhardt, R. G. E. Murray, R. A. Wood \& N. R. Krieg. Washington, DC: American Society for Microbiology.

Sohn, J. H., Kwon, K. K., Kang, J.-H., Jung, H.-B. \& Kim, S.-J. (2004). Novosphingobium pentaromativorans sp. nov., a high-molecular-mass polycyclic aromatic hydrocarbon-degrading bacterium isolated from estuarine sediment. Int J Syst Evol Microbiol 54, 1483-1487.

Stackebrandt, E. \& Liesack, W. (1993). Nucleic acids and classification. In Handbook of New Bacterial Systematics, pp. 158-160. Edited by M. Goodfellow and A. G. O'Donnell. London: Academic Press.

Yoon, J.-H., Kang, S.-J., Lee, S.-Y. \& Oh, T.-K. (2005a). Maribacter dokdonensis sp. nov., isolated from sea water off a Korean island, Dokdo. Int J Syst Evol Microbiol 55, 2051-2055.

Yoon, J.-H., Lee, M.-H., Oh, T.-K. \& Park, Y.-H. (2005b). Muricauda flavescens sp. nov. and Muricauda aquimarina sp. nov., isolated from a salt lake near Hwajinpo Beach of the East Sea in Korea, and emended description of the genus Muricauda. Int J Syst Evol Microbiol 55, 1015-1019. 